\title{
Life Skills Potential Mapping of School Students in Rural and Urban Area
}

\author{
Nurul Ulfatina, Amat Mukhadis ${ }^{\mathrm{b}}$

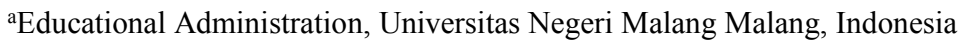 \\ Corresponding e-mail: anurul.ulfatin.fip@um.ac.id
}

\begin{abstract}
Education in rural area become a strategic issue in Indonesia's national development. The learning and occupational curriculum that orient towards life skills education is considered as appropriate for rural schools. The curriculum implementation requires precondition of potential student mapping. This study is intended to examine the differences in student's life skills potential in the rural and urban area for the curriculum effectiveness. With a survey method that involved Junior High School students in the rural and urban areas of Trenggalek and Ngawi regencies, East Java is known have life skills potential that include personal skills and social skills aspects that are different significantly. Of the nine aspects measured, in rural students, there are three aspects, namely independence, leadership, and co-operation with average score higher than urban students. While in the urban students there is no outstanding average score for all measured aspects.
\end{abstract}

Keywords: life skills, personal skills, social skills, rural schools, urban schools

\section{INTRODUCTION}

The life problems are complex, because of that students must be prepared well to face them. The complexity can be seen from two sides, external and internal. The external relates to the environment in which the student is living, while the internal is related to their developmental age. To overcome this very complex life problem requires life skills, which by the World Health Organization [1] is stated as "life skills are abilities for adaptive and positive behaviors, enable individuals to deal effectively with the demands and challenges of everyday life".

Many experts have reviewed life skills. Kendall and Marzano[2] divide the skills into five: (1) selfawareness, (2) thinking skills, (3) social skills, (4) academic skills, and (5) vocational skills. Researchers simplify by classifying life skills into two namely hard skills and soft skills. Hard skills means mastery of science, technology, and technical skills related to a particular field of science, while soft skill is a person's skills in making relation to others (interpersonal skills) and skills in selfmanagement (intrapersonal skills) capable to develop performance maximally. The Indonesian government through The Ministry of Education and
Culture (MoNE) [3] also reduced the grouping of life skills, namely generic life skills and specific life skills. Generic life skills consist of personal skills and social skills, while specific life skills consist of academic skills and vocational skills.

Taking into account the grouping of life skills mentioned above, which is discussed in this study focused on soft skills as generic life skills as stated by MoNE. The focus limitation on generic life skills is intended to show more coverage in terms of management or managerial levels of educational units and not in particular areas of study. The scope of limitation beside refers to the work of Kendall and Marzano [4], also refers to other relevant works. In this study, life skills are identified with the term of character education developed by Lickona [5] which consists of "moral knowing, moral feeling, and moral action". The term continues to grow, which can then be associated with the work of Goleman [6] and Gardner [7] by calling the term intrapersonal and interpersonal. The most recent work referred to is called human values, educare or latent human values, virtue or virtue values (Carr in Nucci and Narvaez [8]), which Nucci and Narvaez [9] subsequently reduced to moral and character. 
Life skills with the term variants as discussed in this study are seen from two sides that is related to the self-potential (personal) and related to the relationship with others and the environment (social). Personal life skills are an individual's ability to recognize self-potential and effectively overcome the daily life demands and challenges. The personal aspects are reflected in indicators such as awareness potential and self-deficiency, parental potential support, independence, school potential, ideals and expectations. While social life skills interpreted as the ability of individuals to communicate / interact and help others and the environment in daily life. Social aspect is reflected from indicators such as leadership, cooperation, empathy, and sportsmanship.

Life skills position for children and youth (in this case including in junior high school age children) is a common foundation for the formation of psychosocial competence. It is said by the WHO that school programs for children and adolescents are essential for promoting psychosocial competence. Psychosocial competence in this case is interpreted as "... a person's ability to deal effectively with daily life demands and challenges of everyday life". A person who has high psychosocial ability, he will be able to maintain his mental health and demonstrate behavior that is adaptive and positive in interacting with others. In other words, life skills can be interpreted as the way a person lives to interact with his environment.

As known, that teenagers and youth in their daily lives face many problems related to their mental existence, health in interaction and the health of their behavior. WHO puts life skills on the links between motivating positive knowledge, attitude and values, and positive behaviors in an effort to prevent early on from life issues. The position of life skills can be illustrated in Figure 1.

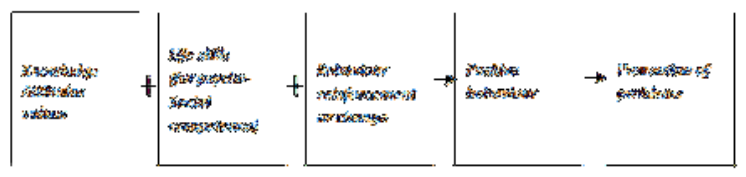

Figure 1 Position of life skills in a series of knowledge, attitude and values with behaviour change factors (Adaptation from WHO [10])

As found in several studies, there is a decrease in moral behavior of school students from the rules of cultural and religious norms, due to the low level of intrapersonal and interpersonal skills in students. The decline in behavior and moral attitude of students is felt in all levels of education. Interpersonal and intrapersonal skills are included into the realm of personal skills and social skills that become an integral part with other life skills. In broader study, as proposed by Kendall and Marzano [11], the position of life skills becomes one of aspects that must be owned and controlled by the learners community so that they can take part in the work field. Many who agree that life skills should be taught to children from kindergarten to Senior High School. However, WHO puts the importance of life skills education especially for adolescents (junior high school age). This is due to the position of junior high school adolescents who in developmental age are in transition from childhood to adulthood [12].

Based on research conducted by the author in the last three years, it is very important and possible the integration of life skills into the Junior High School curriculum. The integration can be divided into four groups, namely (1) core learning, (2) local content, (3) self-development in extracurricular form, and (4) independent activities. The four curriculum content must be complementary and integrated. In addition, it was found that the curriculum of schools in remote and rural areas should be specially designed and not be confused with other schools (especially in urban areas). A suitable curriculum for rural and remote junior high schools is a curriculum loaded with life skills beyond the regular school curriculum [13].

Other facts that support the integration of life skills into rural school curricula because: (1) $80 \%$ of junior high school graduates do not continue to senior high school, (3) all children in rural junior high school have elderly people with low economic level (poor), (4) more than $50 \%$ of junior high school students in rural areas are supported by parents who have a desire for their children to work immediately and earn money for daily needs; (5) the curriculum needed for rural junior high school is a more oriented for the formation of work skills [14].

The results of curriculum testing conducted by researchers showed that (1) the curriculum of learning and working is very effective for the rural junior high school with characteristic as mentioned above, (2) the core curriculum of learning and working is realized in the form of activities on the vocational subjects and others in an integrated way with theme of working field (3) the competencies achieved from the application of the learning and work curriculum, in addition to emphasizing the material mastery, as well (even) more emphasis on the working skills ability, (4) the practice of the vocational thematic learning action can increase processes meaningfulness and learning outcomes, 
particularly in relation to student activity and students' readiness to gain experience in achieving work skills competence at the pre-vocational skills level, and (5) the implementation of the learning and work curriculum requires the active support of all teachers and parents because of the implementation used integrated learning that combines activities on core learning, local content, and autonomous activities at home [15] .

Based on the study results can be concluded that the content of life skills values presented in the Junior High School curriculum has not been maximized. To develop it, it needs mapping and exploring the range of life skills values raised from learners potential. Mapping needs to be sorted between the already advanced and the less advanced schools. Schools that are classified as advanced are generally located in urban areas, while less advanced schools are located in rural areas. By mapping the life skills potential of these two school groups, it is hoped further curriculum development that more realistic and implementative.

\section{RESEARCH METHODS}

This research was conducted by survey method. The survey purpose was to find out the differences in life skills values held by students in rural and urban schools. The survey was conducted in East Java with population of all junior secondary schools. Samples are selected in stratified proportional sampling. At the first stratum level, it was selected the sample proportion of regencies in East Java (1) Trenggalek regency, and (2) Ngawi regency. At the second level the school sample was selected. The selection of school samples in each region sample were grouped into two: less advanced category Junior high school in rural and junior high school category in urban areas. The second grouping is based on data at the Education Agency Office in the two regencies. Based on the data in both education offices, the less advanced category (in rural areas) is identified with unaccredited junior high school up to maximum of $\mathrm{C}$ accreditation, while the advanced category junior high school is identified with A accreditation. Furthermore, at the third level, students sample was determined $30 \%$ for urban junior high school and $10 \%$ for rural junior high school, so that obtained sample of 140 students.

Data collection was done by structured questionnaire. The questionnaire instruments measure the variables of general life skills that are translated into personal skills and social skills. The measured aspects of personal skills are selfpotential-awareness, parental support, self-reliance, the introduction of school potential, and ideals or expectations. While the measured aspects of social skills is leadership or ability to influence others, cooperation and communication, empathy and sportiveness. The questionnaire instrument was developed by researchers. Therefore, it is tested first to know the validity and reliability. In the questionnaire instrument, the construct validity is emphasized on the instrument items compilation based on the clarity of the operational definition. Testing of construct validity involves three steps: (1) articulating a set of theoretical and interrelation concepts, (2) developing a way to measure the hypothetical construct being theorized, and (3) empirically testing the hypothetical relationship between the constructs. Determination of validity used Product Moment formula. The results showed that most questionnaire items are larger than rtable, so it was decided to be used as tool for collecting research data through 28 items of likert scale questionnaire. Meanwhile, the reliability test is used as a guarantee and the form of accountability for effectiveness (accuracy) was done by using Cronbach Alpha coefficient [16]. The results showed that the reliability coefficient of questionnaire instrument obtained by Cronbach's Alpha of 0.63, which can be interpreted as reliable.

Data analysis techniques used in this survey are descriptive statistical technique and inferential statistical technique. Descriptive statistic technique is used to analyze the categorization of student life skills potential in each sample category, whereas inferential statistic technique used is t-test technique that is technique to know the significance of difference of life skills potential owned by students in junior high school which is categorized as rural and urban junior high schools.

\section{RESEARCH RESULT}

The results of this study begins with the presentation of values data from all samples that can be briefly seen in Table 1.

To perform statistical analysis (variance test), before the prerequisite analysis test, consisting of normality test and homogeneity test. The results of the data normality test as given in Table 2 can be expressed in normal distribution. While the 


\begin{tabular}{|c|c|c|c|c|c|c|c|}
\hline & N & Range & Minimum & Maximum & Mean & Std. Deviation & Variance \\
\hline Rural Junior High School of_Kampak (Trenggalek) & 30 & 9 & 55 & 64 & 59.40 & 2.594 & 6.731 \\
\hline Urban Junior High School of Pogalan (Trenggalek) & 30 & 17 & 45 & 62 & 53.67 & 4.626 & 21.402 \\
\hline Rural Junior High School of Kasreman (Ngawi) & 40 & 22 & 56 & 78 & 65.10 & 5.732 & 32.862 \\
\hline Urban Junior High School of Ngawi 2 (Ngawi) & 40 & 26 & 36 & 62 & 51.43 & 6.827 & 46.610 \\
\hline
\end{tabular}

homogeneity test results as given in Table 3 can be stated that the data from Junior High School in Trenggalek Regency (Kampak and Pogalan) are not homogeneous, so for variance test used non parametric analysis, while the data from Junior High School in Ngawi Regency (Kasreman and Ngawi 2) are homogeneous, so for variance test used parametric analysis.

Table 2 Test Results of Data Normality of Life Skills Values for Junior High School Students

\begin{tabular}{ccll}
\hline \multicolumn{1}{c}{ Sekolah } & $\operatorname{Sig}(\mathrm{p})$ & Condition & Conclusion \\
\hline $\begin{array}{l}\text { Rural Junior High } \\
\text { School of Kampak }\end{array}$ & 0,338 & $>0,05$ & Normal \\
Urban Junior High & 0,732 & $>0,05$ & Normal
\end{tabular}

School of Pogalan

Table 3 Test Results of Data Homogeneity of Life Skills Values for Junior High School Students

\begin{tabular}{|c|c|c|c|c|c|c|c|c|c|c|}
\hline Cass & & $\mathrm{x}$ & sh & $d 2$ & Fing & Fore & $\begin{array}{l}\text { Condtho } \\
1\end{array}$ & sig & $\begin{array}{l}\text { Conditsa } \\
2\end{array}$ & Cearlarioe \\
\hline Treadeltes & 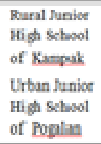 & 30 & 1 & 58 & 7939 & 4,007 & $\frac{E_{\text {nail }}}{F_{\text {and }}}>$ & 0,007 & sis $<0,05$ & $\begin{array}{l}\text { Not } \\
\text { hom growas }\end{array}$ \\
\hline Ngmi & 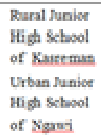 & 40 & 1 & 78 & 1,564 & 3963 & $\begin{array}{l}F_{m=1} \\
E_{n=1}\end{array}$ & 0.315 & $58>0,05$ & Homsposes \\
\hline
\end{tabular}

Table 4 Variance Test of Life Skills Value for Urban and Rural Junior High Schools

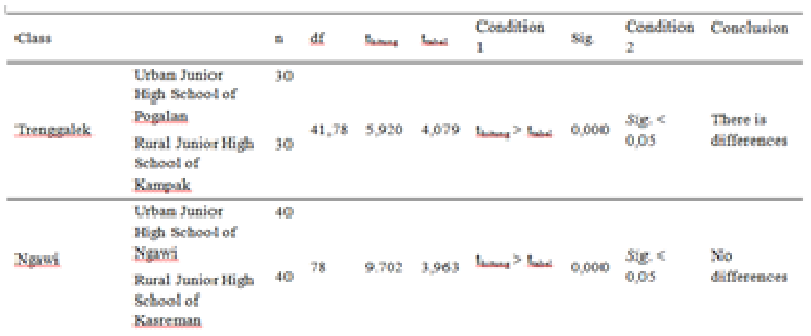

Based on Table 4 it can be seen that the tcalculation of all schools is greater than the $t_{\text {table }}$ $\left(t_{c a l c u l a t i o n}>t_{t a b l e}\right)$ and the significance value is less than 0.05 , so it can be said that there is a significant difference between the urban school category and the rural schools category in each Each regency. In Trenggalek regency, the Pogalan urban junior high school data differs significantly with Kampak rural
High school with $\mathrm{t}_{\text {calculation }}=5,920$ and sig. $=0,000$. Meanwhile, in Ngawi, Ngawi urban junior high school data differs significantly with Kasreman rural junior high school with $\mathrm{t}_{\text {calculation }}=9,702$ and sig. $=$ 0,000 . Thus it can be concluded that there are significant differences in the life skills potential of students in urban junior high school category and rural junior high school category in each regency.

Viewed from the descriptive data, the frequency of each sample group can be seen that there are three aspects from nine aspects of life skills that are measured, in rural junior high school students seem very prominent, namely the aspect of independence that is part of the personal skills variable with mean 3.8, willing to help others, leadership and cooperation that are part of the social skills variable with mean of 3.7 and 3.9 respectively. While in the sample students of the urban group there is no prominent mean value of all indicator aspects of the measured variables.

\section{DISCUSSION}

Based on the research results that have been presented above, it can be discussed as follows. The result of variance test analysis about the potential of life skills values conducted to junior high school students in four groups of sample areas can be concluded that there are significant differences for all sample groups. Thus, it can be concluded that overall there are significant differences in potential of life skills values among junior high school students in rural and urban areas. This implies that different environmental conditions will have impact on the different value potential of life skills. Different conditions include family social economy, natural environment, and school conditions. Based on the results of descriptive analysis, it can be seen that all students who attend school in rural junior high school come from families with low economic status, while students in urban junior high school come from diverse families (low to medium and high). Thus it can be said that differences in conditions experienced by students as found in this study, can potentially impact on the outcomes of life skills learning achievement. These differences can also have impact on educational outcomes, and will in turn have an impact on overall human resources. 
The difference in life skills potential of rural junior high school and urban junior high school students also means that there is a gap between rural students and urban students. A very urgent gap to note is the education service. It is evident that schools in urban areas generally follow a minimum standard with school accreditation status in categories B up to A. Meanwhile, in rural schools, most have not been accredited or maximum in category $\mathrm{C}$. If it is associated with educational services. It can be said that equal distribution of quality education service not occurs. Thus, the mission of education for all as proclaimed by Unesco which then ratified by the Indonesian government for nine years compulsory education program has not been done well. Equity of education in this case just interpreted merely the existence of educational institutions, but have not paid attention more specifically and detail to the standard of service quality.

It can be explained further that the factors of failure in educating children in school is not on cognitive ability, but rather on the psychosocial ability of children, especially on emotional and social intelligence. These abilities include: (1) confidence, (2) self-control, (3) cooperative ability, (4) social interaction, (5) concentration, (6) empathy and (7) communication ability. All these abilities are categorized into personal skills and social skills that have received less attention from educators, especially in primary education. The results of this study can be grouped into the generic skills that must be owned by every individual. This generic skill can be demonstrated through personal abilities (the ability to manage emotions, make rational decisions, design the future), and social skills (the ability to cooperate and understand others). Nucci and Narvaez [17] in their editorial summary based on the results of a number of studies also concluded a relatively similar thing that schools should contribute to the development and formation of student character. In summary, currently $80 \%$ of the country is carrying this mandate. Public expectations, schools become places where children get support for value formation such as honesty $(97 \%)$, respect for others $(94 \%)$, and democracy $(93 \%)$. From a number of study results can be summarized that to form a person with good character and success in life not only from intellectual intelligence alone, but also from emotional intelligence (intrapersonal) and social (interpersonal) intelligence. Both intelligences can affect the behavior of one's intelligence in determining the type of behavior that will be done in interacting with self and in interacting with others.

Differences and gaps in educational conditions between rural and urban areas as found in this study as material for solving the problems of curriculum development and implementation. In addition to possible solutions through collaboration and partnership of rural and urban schools, or at least make the gap not wider. This is as much done by Australia, both through academia and government that have more attention toward efforts to improve education in rural areas, so that education in the village is no less competitive compared with education in the city. Or, education in the village has its own advantages in accordance with the potential of the village. As the Department of Education and Training [18] does, they specifically develop action plans specifically aimed at improving the quality of education in the village. Similarly in Victoria, through the Department of Education and Early Childhood Development (DEECD) has implemented a number of activities devoted to solving rural education problems [19]. In Quensland also doing the same, the government implemented a special educational action framework for rural and remote areas [20]. A more strategic point is also shown by Halsey, Drummond, and Breda [18] through the curriculum by saying that "the Australian curriculum is being introduced to equip all young Australians with the essential skills, knowledge and capabilities to thrive and competence in a globalized world and information rich work-places of the current century ". Based on this description, it can be concluded that the potential of students in rural junior high school different with the potential of junior high school students in urban area reciprocally influence the education service and affect the overall educational achievement.

As the Autralia government exemplifies, the consequences from the more specifically addressing rural schools, the most important from the study is no one denies that life skills values should be provided and developed in schools. Development of life skills in schools has become a concern since many governments have issued rules and guidelines on the implementation of life skills education which is divided into four groups of skills, namely (1) personal skills, (2) social skills, (3) academic skills, and (4) vocational skills. If we refer to the various life skills as described above, then the first two types of life skills, personal skills consisting of selfawareness and thinking skills, and both social skills can be grouped again into general life skills. While the other two life skills groups, namely academic skills and vocational skills are grouped as specific life skills. It is further explained that specific life skills can be studied directly as reflected in the subject or field of study and the course of study selected by the students in the school. Implementation of specific life skills is of much concern especially in the Directorate of Secondary 
Education, Directorate of Vocational Education, and Directorate of outside School Education [3]. This is very reasonable because the three directorates deal with learners in which they are in the most strategic position in preparing prospective workers. Meanwhile, it is further explained that general life skills (personal skills and social skills) should be paid more attention by the Directorate of Primary Education (including junior high school education) because at the elementary level education is intended to provide experience in basic life as well as for the initial provision of motor skills and their familiarity in real life in field.

The importance of life skills provision in schools, especially junior high school whose students in the category of adolescents is explained from the experience of WHO [1], which teenagers and youth get learning life skills through learning and practice. Development of life skills through learning and practice is explained through Bandura's theory of social learning theory, that "learning is considered to be active acquisition, processing and structuring of experiences". In this context, the method used depends greatly on how adolescent and youth can learn from their experiences, the people in the immediate environment, from their observations, and from the consequences they have to make on the experience and observation.

Education and life skills development in schools is effective by involving children dynamically in the learning process. Methods that can facilitate the active involvement of students include (1) working in small groups and pairs, (2) brainstorming, (3) role plays, (4) games, and (5) debates. Life skills lessons can be started from the teacher by exploring with the students what their ideas and knowledge about the current situation in which life skills can be used. Children can ask each other questions and discuss the emerging issues of their group, followed by playing roles to show the required practical skills. And so on, ultimately the teacher can help design the tasks that must be done at home, which requires the child to discuss further and practice his skills with his family, neighbours, and peers.

Development of life skills in teaching and learning activities as described above can be started from the integration of life skills values into the curriculum and classical and regular learning. Integration through the curriculum can be done by organizing the curriculum. In theory, the junior high school curriculum is very appropriate when presented in the form of correlated curriculum organization, broad field curriculum, and integrated curriculum [21]. Looking at the curriculum complexity, it must be grouped by its urgency. For the Junior high school curriculum, the many groupings are divided into three, namely core curriculum, extra curriculum, and local curriculum (Tanner \& Tanner [20]; Stoops, Rafferty, and Johnson [19]). The curriculum grouping based on this urgency should consider the competence domain to be achieved. The most heavily referenced domain grouping is the Bloom model that sort the domains based on the taxonomy of educational goals, i.e. cognitive, psychomotoric, and affective [20].

\section{CONCLUSIONS AND RECOMMENDATIONS}

Based on the results and discussion it can be concluded that the life skills potential of junior high school students in rural areas differ significantly with the life skills potential of junior high school students in urban areas. Aspects of independence as part of the personal skills potential, and leadership aspects, and cooperation as part of social skills in junior high school students in the rural area seem very prominent or high. Meanwhile, in junior high school students in urban areas, out of all nine aspects measured does not seem high.

Based on this conclusion, some suggestions can be given as follows. For the Local Government, in this case the Regency / City Education Agency should map each school potential with each background variant continuously. It is very important to know the progress level of a region, so that ultimately can be determined the type, shape, and nature of educational services, especially curriculum programs that better suit their needs. For the Central Government, in this case the Ministry of Education and Culture, the results of this study should be a consideration to make the needed policies for the variations development of curriculum programs, both from the organizational structure, the content of lessons, and the learning achievements. For headmasters and teachers (especially in junior high schools) it is advisable to develop a contextual experiential curriculum according to the student background. At headmasters and teachers in rural junior high schools, it is advisable to pay attention to aspects of self-reliance, leadership and cooperation as main potential of students and as a motivating material for students to pursue higher studies. As for headmasters and teachers in urban junior high school is advised to make school programs that can generate and explore the potential of their students.

\section{REFERENCES}


[1] World Health Organization (WHO).1997. Life Skills Education in Schools. Division of Mental Health and Prevention of Substance Abuse, World Health Organization. WHO/MNH/PSF/ 93.7A.Rev.2, 2806623131.

[2] Kendall, J.S. \& Marzano, R.J. 1997. Content Knowledge: A Compedium of Standards and Benchmarks for K-12 Education. Aurora, Colorado: McREL, Mid-continent Regional Educational Laboratory; Alexandria, Virginia: ASCD.

[3] Departemen Pendidikan Nasional. 2002. Pendidikan Berbasis Keterampilan Hidup (Life Skills) melalui Pendidikan Broad Based Education. Jakarta: Ditjen PLS dan Pemuda, Depdiknas.

[4] Kendall \& Marzano. Loc. Cit.

[5] Lickona, T. 1992. Educating for Character, How Our Schools Can Teach Respect, Respect and Responsibility. New York: Bantam Books.

[6] Goleman, D. 1995. Emotional Intelligence. New York: Bantam Books.

[7] Gardner, H. 1996. Intelligence: Multiple Perspectives. Harcourt Brace College. Fort Worth. Tex.

[8] Carr, D. 2014. Pendidikan Karakter sebagai Penanaman Kebajikan. In Nucci, L.P. and Narvaez, D. Handbook of Moral and Character Education. New York: Routledge. Translated by Penerbit Nusa Media, Bandung.

[9] Nucci, L.P. \& Narvaez, D. (Ed). 2014. Handbook of Moral and Character Education. New York: Routledge. Translated by Nusa Media Bandung.

[10] Monks, F.J., Knoers, A.M.P., \& Haditono, S.R. 2001. Psikologi Perkembangan: Pengantar dalam Berbagai Bagiannya. Yogyakarta: Gadjah Mada University Press.

[11] Ulfatin, N. dan Mukhadis, A. 2015. Pengembangan Kurikulum Belajar dan Berkarya ("Jalakar") untuk Meningkatkan Kebermaknaan Hasil Pembelajaran Siswa SMP Satu Atap sebagai Program Wajib Belajar 9 Tahun di Daerah Terpencil. Rancangan Penelitian Tahun 3. Malang: LP2M Universitas Negeri Malang.

[12] Ulfatin, N., Mukhadis, A. dan Imron, A. 2013. Kurikulum Belajar dan Berkarya ("Jalakar") untuk SMP Satu Atap. Jurnal Pendidikan. Jilid 40, No.2.178-193.

[13] Ulfatin, N. dan Mukhadis, A. 2014. Pengembangan Kurikulum Belajar dan
Berkarya untuk Meningkatkan Kebermaknaan Hasil Pembelajaran Siswa SMP Satu Atap sebagai Program Wajib Belajar 9 Tahun di Daerah Terpencil. Laporan Penelitian Tahun 2. Malang: LP2M Universitas Negeri Malang.

[14] Mukhadis, A. 2016. Metodologi Penelitian Kuantitatif: Bidang Pendidikan dan Contoh Aplikasinya. Malang: Aditya Media Publishing.

[15] The Queensland Government. 2015. Action Plan for Rural and Remote Education 20112015. Department of Education and Training. Queensland Government.

[16] VAGO. 2014. Access to Education for Rural Students.Victorian Auditor-General's Report. April 2014.

[17] The State of Queensland. 2003. Rural and Remote Education Framework for Action 20032005. Queensland Government.

[18] Halsey, J., Drummond, A., dan Breda, M.v. 2010. Implementing the Australian Curriculum in Rural, Regional and Remote Schools, and Schools of Distance Education. Online. www.flinders.edu.au/educationa/rural8 September 2010.

[19] Tanner, D. \& Tanner, L.N. 1980. Curriculum Development, Theory into Practice. New York: Macmillan Publishing Co, Inc.

[20] Stoops, E.; Rafferty, M. \& Johnson, R.E.1981.Handbook of Educational Administration. A Guide for the Practitioner. Second Edition, Boston: Allyn and Bacon, Inc.

[21] R. Fogarty. 1993. The Mindful School: How to Integrate the Curricula. Hawker Brownlow Education: Skylight Publishing, Inc. 